\title{
ROLA REHABILITACJI, MODERNIZACJI I ADAPTACJI BUDYNKÓW ZABYTKOWYCH W PROCESIE REWITALIZACJI
}

\begin{abstract}
Celem artykułu jest ukazanie roli rehabilitacji, modernizacji i adaptacji - głównych działań inżynierskich, w procesie rewitalizacji budynków zabytkowych. W oparciu o własne doświadczenia, w działalności inżynierskiej i naukowej, autor dokonuje analizy tego procesu, ukazuje problemy i zagrożenia oraz definiuje poszczególne działania. Są to działania różniące się od siebie, uzupełniające się jednak i wynikające z siebie nawzajem. Mają one bardzo złożony charakter i powinny być odpowiednio zaplanowane i koordynowane w czasie realizacji. Powinny być realizowane zgodnie z programem konserwatorskim, uzgodnionym i zatwierdzonym przez konserwatora zabytków. Rehabilitacja budynku zabytkowego odnosi się do konstrukcji, formy, w tym wszystkich detali i elementów architektonicznych, nadających wartość estetyczną zabytku, instalacji i wyposażenia. Modernizacja budynku zabytkowego zwiększa jego wartość użytkową - walory funkcjonalne, estetyczne oraz komfort użytkowania. Wszystkie działania rehabilitacyjne, modernizacyjne, adaptacyjne, w powiązaniu z badaniami i działaniami diagnostycznymi powinny być wykonywane w sposób prawidłowo zaplanowany i skoordynowany (uwzględniający istotna rolę konserwatora zabytków). Każdy budynek zabytkowy powinien być zaadoptowany do współczesnych wymagań użytkowych. Zdolność adaptacyjna budynku, układu architektonicznokonstrukcyjnego, ustroju nośnego, elementu konstrukcyjnego jest zespołem cech i właściwości, określających łatwość adaptacji do nowych warunków konstrukcyjnych (pracy w nowych układach konstrukcyjnych, implikujących nowe schematy statyczne, możliwości ich zmian, napraw, wymian, możliwości zmian obciążeń itp.) lub użytkowych. Wartość zdolności adaptacyjnej może być określona po przeanalizowaniu wielu cech i właściwości. W artykule przedstawiony jest schemat powiązań działań rewitalizacyjnych.
\end{abstract}

Słowa kluczowe: konserwacja zabytków, zdolność adaptacyjna, zasady zrównoważonego rozwoju

\footnotetext{
${ }^{1}$ Wojciech Terlikowski, Politechnika Warszawska, Wydział Inżynierii Lądowej, Instytut Inżynierii Budowlanej, Aleja Armii Ludowej 16, 00-637 Warszawa, tel.+48 602630 513, email: w.terlikowski@il.pw.edu.pl
} 


\section{Pojęcie zrównoważonej rewitalizacji}

Zasady zrównoważonego rozwoju nakazują szerokie i interdyscyplinarne podejście do wszelkich procesów gospodarczych i społecznych. Szczególne miejsce wśród wszystkich obszarów gospodarki ma budownictwo i procesy związane z projektowaniem i realizacją inwestycji budowlanych, odnoszącymi się zarówno do nowych obiektów budowlanych, jak też do obiektów już istniejących. Zrównoważony rozwój w budownictwie ma kluczowe zadanie w procesie równoważenia gospodarki kraju, ze względu na duży potencjał tego sektora, wynikający z liczby zatrudnionych w nim pracowników, społeczną rolę związaną z ciągłym brakiem zaspokojenia potrzeb mieszkaniowych w kraju, wrażliwość na nowe innowacyjne rozwiązania technologiczne, możliwość wdrażania nowych rozwiązań technicznych, materiałowych oraz obniżenia stopnia emisji i zużycia energii. Istotnym elementem procesu równoważenia gospodarki jest rewitalizacja. Pojęcie „rewitalizacja” oznacza dosłownie „ożywienie, przywrócenie życia". Odnosi się je obecnie do bardzo istotnych, z punktu widzenia gospodarki i zagadnień społecznych, procesów inwestycyjnych, które zmieniają całe obszary, znajdujące się w stanie kryzysowym. Są to obszary w różny sposób zdegradowane, zarówno w wiejskie jak i miejskie. Rewitalizacja dotyczy procesów interdyscyplinarnych, obejmujących złożone zmiany przestrzenne, urbanistyczne, budowlano-architektoniczne, które powinny być przeprowadzone w taki sposób, by obszar został wyprowadzony ze stanu kryzysowego. Najbardziej skutecznie będzie to zrealizowane wówczas, gdy w ramach rewitalizacji usunięte zostaną przyczyny powodujące kryzys, a także rozwiązane zostaną problemy wynikające $\mathrm{z}$ tego stanu i zniwelowane skutki. Obok zmian związanych z gospodarka przestrzenną i budownictwem, rewitalizacja powinna obejmować zmiany społeczne i gospodarcze, będące następstwem działań przestrzenno-budowlanych lub wynikające $\mathrm{z}$ działań równoległych. W rewitalizowanym obszarze istotne znaczenie mają rewitalizowane budynki. W obszarze kryzysowym oraz w budynkach, które na nim się znajdują, powinna być przywrócona funkcja pierwotna lub wykreowana nowa, uwzgledniająca współczesne potrzeby mieszkańców, użytkowników, w tym inwestora, mającego w procesie rewitalizacji znaczenie kluczowe. Wykreowana nowa funkcja obszaru lub poszczególnych obiektów budowlanych, powinna uwzględniać rozwiązanie problemów stanu kryzysowego, usunięcie przyczyn ich powstania, a także stworzenie warunków do dalszego rozwoju. Ponieważ często jest to wartość dodana do efektu ekonomicznego inwestycji budowlanej, inwestorzy często nie dostrzegają w tych działaniach swojego interesu. Działania rewitalizacyjne powinny dotyczyć interesu publicznego, oprócz bezpośrednich zysków wymiernych z ich przeprowadzenia - dodatniego wyniku ekonomicznego inwestycji, ważne są zyski pośrednie - społeczne. Rewitalizacja obszaru kryzysowego powinna powodować pobudzenie aktywności gospodarczej (szczególnie lokalnej, w obszarze małych i średnich przedsiębiorstw, w tym tworzeniem nowych 
miejsc pracy i rynków zbytu), społecznej, inicjować rozwój kultury, edukacji, rozwiązywać problemy socjalne i bytowe ludności. Tylko przyjmując tak szeroki zakres działań mieszczących się w procesie rewitalizacji, można mówić o prawidłowym jej przeprowadzeniu.

Do niedawna pojęcie rewitalizacji odnosiło się przede wszystkim do całych obszarów znajdujących się w stanie kryzysowym i znajdujących się na ich terenie obiektów budowlanych lub ich zespołów. Uwzględniając powyższe założenia pojęcie rewitalizacji można jednak odnieść do pojedynczego obiektu budowlanego - np. budynku lub budowli, które przestały spełniać swoje zadania społeczne i utraciły funkcje użytkowe, zostały zdegradowane lub zniszczone, stając się nierzadko przyczyną sytuacji kryzysowej w otaczającym je obszarze. Wśród takich budynków szczególną rolę odgrywają budynki zabytkowe. Patrząc na proces rewitalizacji przez środowiskowy pryzmat zasad zrównoważonego rozwoju, widać wagę i znaczenie ochrony zabytków. Są one częścią dziedzictwa kulturowego, o znaczeniu lokalnym, krajowym, regionalnym lub nawet globalnym. Najlepszą formą ich ochrony jest właśnie rewitalizacja. Rynek budowlany w Polsce pokazuje, że coraz częściej adaptuje się budynki istniejące, w tym zabytkowe, do współczesnych wymagań użytkowych. Towarzyszy temu często przywrócenie funkcji pierwotnej lub jej zamiana na nowo wykreowaną, uwzględniającą potrzeby zarówno inwestora (związane z planem inwestycyjnym i zagadnieniami komercyjnymi), jak i społeczności lokalnej (wynikające z potrzeby przeprowadzenia przemian rewitalizacyjnych). Dobrym tego przykładem jest rewitalizacja południowej strony Placu Bankowego w Warszawie, ze znajdującym się tu Hotelem Saskim (Rys.1).

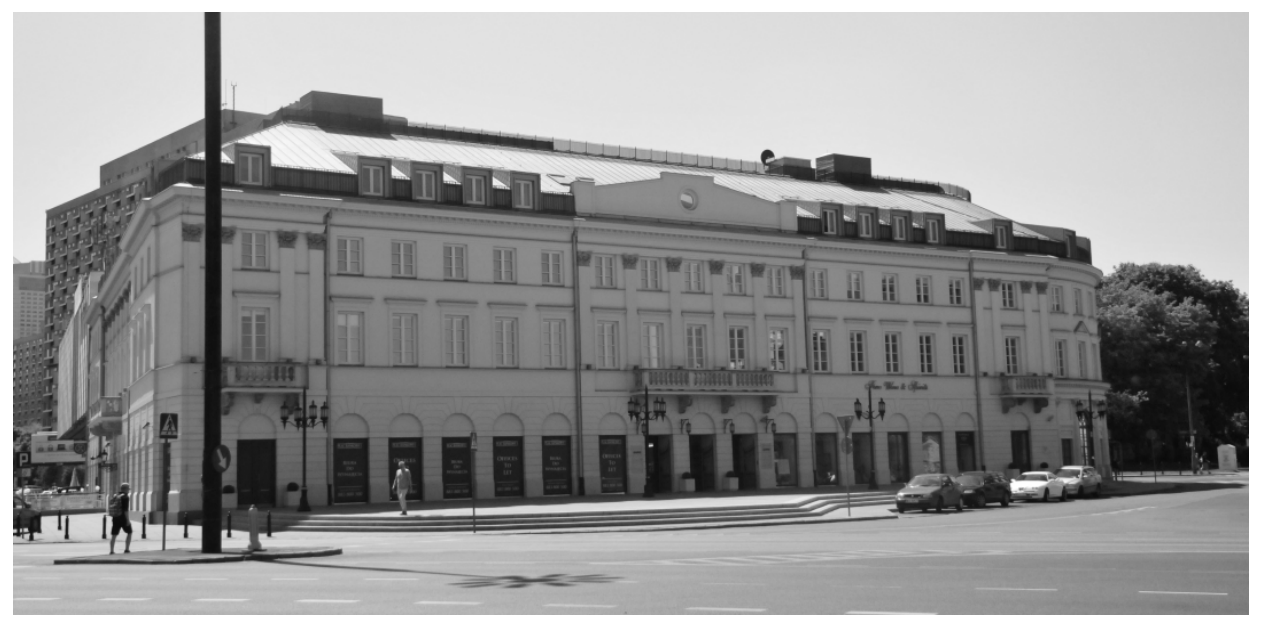

Rys.1. Budynek Hotelu Saskiego po rewitalizacji

Fig. 1. The Saski Hotel after revitalization 
Należy zaznaczyć, że rewitalizowane zabytkowe budynki mieszkalne i użyteczności publicznej, a także budynki poprzemysłowe, nadające się do adaptacji na lofty, są bardzo poszukiwanym towarem rynkowym. Te ostatnie dają możliwość utworzenia w starych magazynach, fabrykach, spichlerzach, hutach, browarach kompleksów pomieszczeń mieszkalnych, charakteryzujących się dużymi, otwartymi przestrzeniami, surowymi wnętrzami z przewagą szkła, stali i kamienia, wysokimi sufitami, wielkimi oknami czy przemysłowym oświetleniem. Oczywiście w wypadku rewitalizacji poprzemysłowych obiektów zabytkowych konieczna jest akceptacja całego procesu ożywienia przez konserwatora zabytków. Aby właściwie przeprowadzić proces rewitalizacji obszaru kryzysowego, ze względu na jego złożoność i interdyscyplinarność, konieczne są szczegółowe badania, zarówno na etapie planowania i projektowania procesu, jak również w czasie jego realizacji [3]. Współpraca nauki i przemysłu ma tutaj znaczenie kluczowe, ze względu na spektrum zagadnień zawartych w procesie rewitalizacji.

Obecnie w Polsce podstawą wyznaczenie obszaru kryzysowego jest krytyczna analiza wyników badań i analiz przeprowadzonych dla potrzeb dzielnicowych mikroprogramów rewitalizacji, z uwzględnieniem poziomu: bezrobocia, ubóstwa oraz trudnych warunków mieszkaniowych, przestępczości, wykształcenia mieszkańców, przedsiębiorczości mieszkańców, degradacji technicznej infrastruktury i budynków, zanieczyszczenia środowiska naturalnego. Każdy obszar jest konsultowany ze społecznością lokalną podczas przeprowadzanych przez urzędy dzielnicowe konsultacji społecznych.

\section{Rewitalizacja budowlanych obiektów zabytkowych}

Zabytki architektury (co wynika z Ustawy o ochronie zabytków [5]) są często wybitnym przykładem dzieła architektury i budownictwa. Dotyczy to zarówno indywidualnych budynków, jak i zespołów budynków. Za zabytki uważa się obiekty budowlane będące wyjątkowym przykładem budownictwa, rzadko spotykanym, charakterystycznym dla danej epoki (w sensie architektonicznym, technologicznym, materiałowym), mogące wpływać bezpośrednio lub pośrednio na rozwój architektury lub technologii budowlanej. Są one często dowodem tradycji kulturowej, świadkiem ważnych zdarzeń historycznych o znaczeniu lokalnym i poza lokalnym. Ta specyfika implikuje specjalne traktowanie tych obiektów, zarówno od strony prawnej (ochrona prawna zabytków) jak i w zakresie diagnostyki, badań, projektowania i realizacji inwestycji rewitalizacyjnej oraz późniejszego użytkowania zabytków zrewitalizowanych (dotyczy to również przestrzeni i obszarów znajdujących się wokół tych zabytków) [1]. Patrząc na ochronę zabytków z perspektywy zasad zrównoważonego rozwoju, można dostrzec jej kluczową rolę. Dziedzictwo kulturowe jest własnością niezbywalną, podstawową, zarówno pokoleń współczesnych jak i przyszłych, ukazującą ciągłość historyczną narodów, społeczeństw i całych cywilizacji. Jest 
w nich zawarta wartość edukacyjna, kształtująca tożsamość społeczną i narodową. Często są one podstawą do określania zasad estetyki kształtowanych w poszczególnych epokach historycznych oraz kanonów ponadczasowych. Ochrona obiektów zabytkowych, zabezpieczenie prawne i techniczne, poprawa trwałości, właściwe ich użytkowanie, a także kompleksowe badania, dokumentowanie i promowanie ich historii oraz wieloaspektowej wartości (historycznej, kulturowej, estetycznej, edukacyjnej) jest podstawowym obowiązkiem, który powinien być realizowany w procesach rewitalizacyjnych. Zapewnia ona dalsze ich istnienie i trwanie dla przyszłych pokoleń. O znaczeniu tych działań świadczą liczne konwencje międzynarodowe, które są prawnymi gwarantami prawidłowego prowadzenia tych procesów, aby nie dopuścić do utraty najważniejszych obiektów dziedzictwa kulturowego na wszystkich szczeblach (światowym, regionalnym, krajowym, lokalnym). Zrewitalizowane obiekty zabytkowe stają się często źródłem rozwoju gospodarczego poprzez rozwój turystyki. Implikują konieczność rozbudowy bazy turystycznej - np. hoteli, restauracji, infrastruktury.

Opuszczone budynki zabytkowe są często przyczyną rozwoju kryzysu w obszarze je otaczającym. Nieużytkowanie starych budynków zabytkowych powoduje w sposób szybki, bezpośredni i pośredni destrukcję tych obiektów. Zwiększa to zagrożenie utraty materialnej substancji zabytkowej, ale również niebezpieczeństwo związane z zagrożeniem życia i zdrowia ludzi, którzy mogą przebywać w obrębie zagrożonego obiektu budowlanego. Użytkowanie takich zabytkowych pustostanów przez osoby nieuprawnione (dzikich lokatorów) może być jednym z najbardziej niebezpiecznych i destrukcyjnych oddziaływań. Można się w tym wypadku spodziewać następujących zagrożeń:

- degradacji, osłabienia i niszczenia ustroju nośnego budynku zabytkowego, poprzez niekontrolowany demontaż materiałów i elementów konstrukcyjnych, nadających się do powtórnego użycia (szczególnie niebezpieczne mogą być wyburzenia ścian konstrukcyjnych lub rozbiórki stropów, wpływające na zmniejszenie sztywności przestrzennej całego ustroju nośnego budynku);

- niszczenia elementów konstrukcyjnych, wykończeniowych, pokryciowych, instalacji i wyposażenia budynku, którego skutkiem może być osłabienie właściwości fizycznych, mechanicznych i wytrzymałościowych elementów konstrukcyjnych budynku (np. wzrost zawilgocenia przegród budowlanych związany z demontażem rynien i rur spustowych);

- kradzieży i niszczenia zabytkowych elementów i detali architektonicznych stanowiących o wartości zabytkowej budynku;

- niekontrolowanej ingerencji w układ architektoniczno-konstrukcyjny poprzez dodatkowe dobudowy, nadbudowy, przebudowy, niszczące oryginalny charakter zabytku i fałszujące prawdę historyczną;

- rozwoju środowiska agresywnego we wnętrzu budynku - rozwój agresji i destrukcji biologicznej, poprzez rozwój pleśni i grzybów spowodowany 
brakiem ogrzewania i wentylacji pomieszczeń;

- syndromu „,chorego budynku”, działający na zdrowie „dzikich lokatorów”;

- degradacji środowiska naturalnego, otaczającego budynek;

- niewłaściwego gospodarowania odpadami na terenie obiektu i w obszarze go otaczającym;

- tworzenia schematów negatywnych zachowań na terenie otaczającym nieużytkowany budynek (patologie społeczne);

- zwiększenia niebezpieczeństwa na drogach komunikacyjnych, znajdujących się w obszarze oddziaływania budynku;

- wyludnienia w okolicy budynku;

- zwiększenie zagrożenia pożarowego.

Powyższe zagrożenia świadczą o tym, że rewitalizacja zabytkowych budynków znajdujących się w obszarze kryzysowym ma kluczowe znaczenie dla całego procesu. Wśród działań podejmowanych w ramach rewitalizacji budynków zabytkowych, najważniejsze znaczenie, z punktu widzenia zagadnień inżynierskich, ma ich rehabilitacja, modernizacja i adaptacja.

\section{Rehabilitacja, modernizacja i adaptacja budynków zabytkowych}

\subsection{Proces rehabilitacji}

Podstawowym zadaniem inżynierskim w rewitalizacji budynku zabytkowego jest zapewnienie stanu bezpieczeństwa konstrukcji i użytkowania [2]. Oznacza to, że stan techniczny konstrukcji budynku nie będzie powodował zagrożenia bezpieczeństwa ludzi znajdujących się w tym budynku oraz w jego bezpośrednim otoczeniu. W żadnym elemencie konstrukcyjnym oraz w całym ustroju nośnym, zbudowanym z tych elementów, nie mogą być przekroczone stany graniczne nośności. W czasie użytkowania budynku nie może również być zagrożone zniszczeniem jego wyposażenie lub przechowywane w nim mienie. Jednocześnie powinien być zapewniony stan przydatności do właściwego użytkowania, co oznacza, że nie powinny występować lokalne uszkodzenia, nadmierne zarysowania, odkształcenia, przemieszczenia lub drgania. Wymagania, w odniesieniu do budynków zabytkowych, znajdujących się w obszarze kryzysowym, podlegającym rewitalizacji, są często trudne do spełnienia. Przyczyną tego jest duży stopień destrukcji konstrukcji (układów i elementów konstrukcyjnych, materiałów). Ochrona konserwatorska nakazuje jednak podejmowanie działań rehabilitacyjnych konstrukcji budynku, będących podstawą jakichkolwiek dalszych działań rewitalizacyjnych. W przypadku budynków, w których stopień destrukcji konstrukcji jest zaawansowany w takim stopniu, że przekroczony jest stan bezpieczeństwa konstrukcji, wszelkie prace należy rozpocząć od inżynierskich działań ratunkowych - zabezpieczeń, konserwacji, wzmocnień, które są podstawą i początkiem procesu rehabilitacji (Rys.2). Re- 
habilitacja konstrukcji budynku zabytkowego oznacza wszystkie działania inżynierskie, mające na celu przywrócenie możliwości pełnienia właściwej funkcji i prawidłowej pracy (np. przywrócenie właściwej nośności, sztywności itp.) całego ustroju nośnego budynku oraz elementów, które go tworzą.

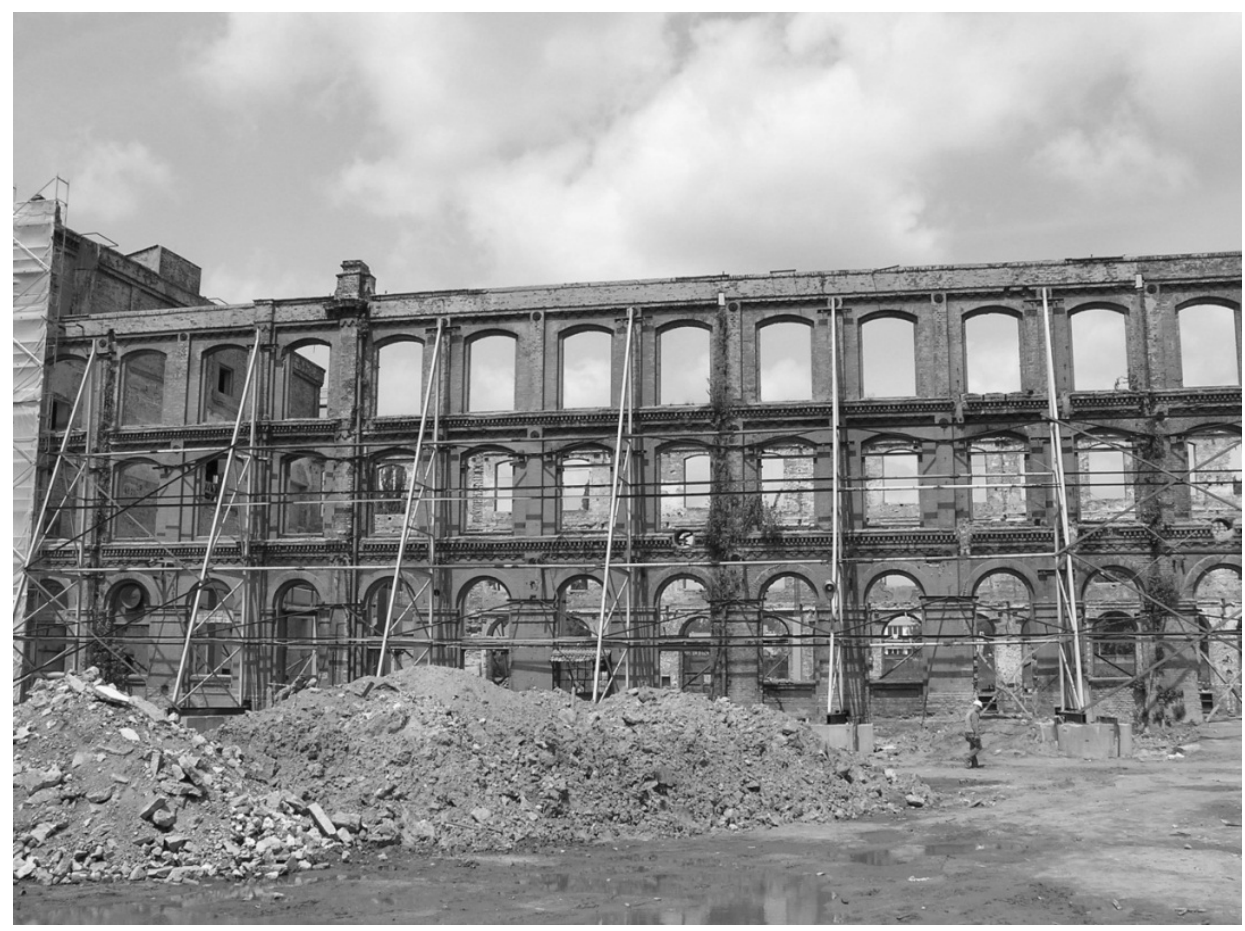

Rys.2. Usztywnienie ściany pozbawionej stropów przyporami (Manuaktura w Łodzi)

Fig.2. Walls devoid of ceiling braced with buttresses (Manufaktura in Łódź)

Szczególnie ważne są tutaj następujące zagadnienia:

- zapewnienie sztywności przestrzennej całego budynku oraz sztywności poszczególnych elementów konstrukcyjnych tworzących ustrój nośny;

- zabezpieczenie stanu istniejącego (jest to działanie szczególnie istotne w przypadku zabytkowych budynków i innych obiektów budowlanych znajdujących się w stanie stałej ruiny - zamków, pałaców, świątyń, fortyfikacji itp.); działania te są często wymuszone przez zagrożenie bezpieczeństwa konstrukcji i użytkowania, są podstawowe i konieczne do podjęcia, aby wykonać działania pozostałe;

- wzmocnienie i naprawa wszystkich elementów konstrukcyjnych, których nośność jest zbyt mała, ze względu na uszkodzenia, zmianę układów statycznych lub obciążeń na nie działających;

- naprawa uszkodzeń, rys, pęknięć, destrukcji; 
- reprofilacja murów;

- osuszenie zawilgoconych elementów konstrukcyjnych;

- naprawa izolacji przeciwwilgociowej i przeciwwodnej;

- wymiana uszkodzonych lub zużytych elementów i układów konstrukcyjnych;

- zahamowanie postępującej destrukcji konstrukcji budynku; w tym obszarze mieszczą się również wszystkie działania konserwatorskie mające na celu zabezpieczenie i utrwalenie struktury zabytku, zahamowanie procesów jego destrukcji oraz dokumentowanie tych działań.

Rehabilitacja budynku zabytkowego odnosi się również do rehabilitacji jego formy, w tym wszystkich detali i elementów architektonicznych, nadających często wartość estetyczną zabytku, a także przywrócenie właściwego, oryginalnego układu architektonicznego, cechującego daną epokę, poprzez usunięcie nawarstwień historycznych, powstałych w czasach późniejszych. Istotnym elementem rehabilitacji budynku jest również rehabilitacja instalacji i wyposażenia, która w wypadku budynków zabytkowych najczęściej sprowadza się do ich modernizacji, z zachowaniem elementów oryginalnych, mających wartość historyczną, estetyczna i zabytkową.

Wszystkie działania rehabilitacyjne dotyczące zabytków powinny być poprzedzone interdyscyplinarnymi badaniami ( $\mathrm{w}$ tym konserwatorskimi, a jeżeli jest taka potrzeba również archeologicznymi). Diagnozowanie budynków zabytkowych, będące podstawą działań rewitalizacyjnych jest działaniem złożonym, trudnym i indywidualnym, odnoszącym się zawsze do konkretnego obiektu, zależnym od wielu czynników oddziaływujących na ten obiekt współcześnie jak również w ciągu jego historii - zarówno w okresie jego projektowania, jak i realizacji i użytkowania. Prace rehabilitacyjne, w tym przede wszystkim wszystkie działania konserwatorskie, powinny być prowadzone zgodnie ze sztuką konserwacji i międzynarodowymi ustaleniami. Te najważniejsze zawarte zostały w tzw. kartach, wśród których do najważniejszych można zaliczyć Kartę Ateńską z 1931 roku oraz Kartę Wenecką z roku 1964. Karty te wprowadzają szereg szczegółowych uregulowań procesu konserwatorskiego, wśród których do najważniejszych należą: unikanie rekonstrukcji, aby zachować autentyczność zabytków; dopuszczenie rekonstrukcji w sytuacjach wyjątkowych, gdzie poprzez szczegółowe i rzetelne badania wyeliminowana jest kreatywność współczesnego projektanta (zachowana jest autentyczna forma, układ architektoniczno-konstrukcyjny, oryginalne technologie wykonania i materiały); metodą takiej rekonstrukcji powinna być anastyloza, czyli ponowne zmontowanie zrujnowanej budowli, jej części lub odbudowa przy użyciu zachowanych oryginalnych fragmentów; zachowanie nawarstwień stylowych budynku, ukazujących rozwój jego formy na przestrzeni historii; stosowanie nowoczesnych materiałów i osiągnięć techniki w taki sposób, by nie były one widoczne i nie naruszały wyglądu oraz oryginalnego charakteru obiektu budowlanego; nowe materiały 
powinny być, w miarę możliwości, odróżnione od oryginalnych; dobudowy mogą być dopuszczalne tylko wtedy, gdy swoją formą i rozwiązaniami technologiczno-materiałowymi nie ingerują zbytnio w zabytek dominując go, nie zaburzają równowagi kompozycji i związków ze środowiskiem oraz przestrzenią otaczającą. Wszystkie działania rehabilitacyjne muszą bezwzględnie uwzględniać program konserwatorski, zatwierdzony przez konserwatora zabytków.

\subsection{Modernizacja}

Modernizacja budynku zabytkowego jest zespołem działań, których celem jest ulepszenie, unowocześnienie, uwspółcześnienie obiektu budowlanego. Przez te działania zwiększa się jego wartość użytkowa - walory funkcjonalne, estetyczne, komfort użytkowania. Również modernizacja budynku zabytkowego, jego części, instalacji lub wyposażenia może być wykonana tylko wówczas, gdy uzyska aprobatę konserwatora zabytków. Typowym przykładem modernizacji jest termomodernizacja, która zakłada poprawienie efektywności energetycznej budynku, która w budynkach zabytkowych często nie może być wykonana $\mathrm{w}$ sposób klasyczny (ocieplenie od zewnątrz). Modernizacja instalacji i wyposażenie budynku zabytkowego w nowoczesne, efektywne energetycznie urządzenia skutkuje zazwyczaj dużą ingerencją w istniejącą strukturę budynku. Wykonywanie nowych otworów w przegrodach budowlanych (zarówno stropach jak i ścianach) wymusza konieczność szczegółowej analizy konkretnych przypadków i wykonania wzmocnień lub zastosowania nowych rozwiązań technicznych. Należy przy tym zaznaczyć, że ograniczenie emisji gazów cieplarnianych oraz uwzględnienie w procesie rewitalizacji środowiska naturalnego powinno implikować stosowanie innowacyjnych, energooszczędnych rozwiązań materiałowych i technologicznych

\subsection{Adaptacja i zdolność adaptacyjna budynku zabytkowego}

Każdy budynek zabytkowy powinien być zaadoptowany do współczesnych wymagań użytkowych. Jak zaznaczone zostało w rozdziale pierwszym, związane jest to często $\mathrm{z}$ wprowadzeniem nowej funkcji, która została wykreowana w procesie rewitalizacji obszaru kryzysowego. Z nowej funkcji wynika często nowe założenie funkcjonalno - użytkowe, które również musi uzyskać akceptację konserwatora zabytków. Adaptacja do nowych wymagań użytkowych, zakłada również dostosowanie komfortu użytkowania do współczesnych oczekiwań. Wyjątkowo ważne jest zaadaptowanie budynku do potrzeb osób niepełnosprawnych (Rys.3). Można tutaj zauważyć, że różne budynki, a właściwie różne układy architektoniczno-konstrukcyjne, ustroje nośne, poszczególne elementy konstrukcyjne mają różną wrażliwość na zmiany i adaptację. Możemy ją określić mianem zdolności adaptacyjnej. 


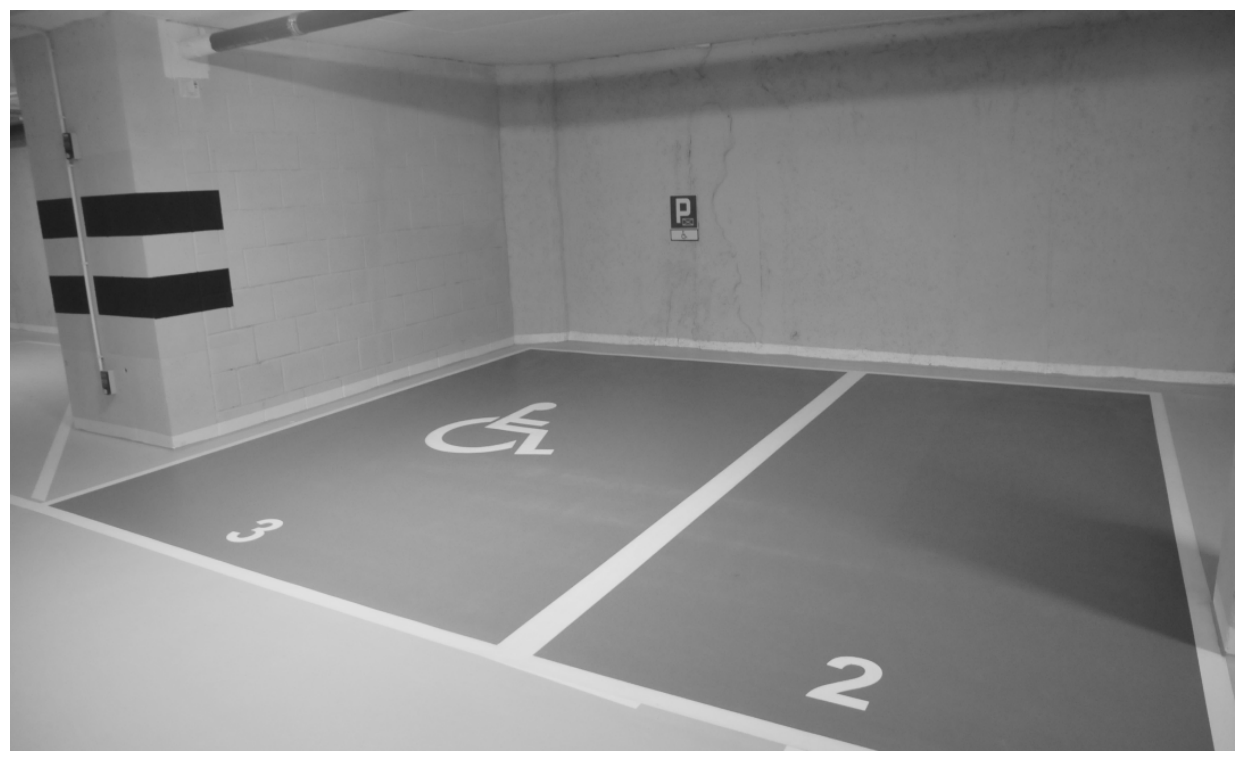

Rys.3. Miejsca postojowe dla osób niepełnosprawnych w garażu podziemnym wykonanym przy rewitalizacji Hotelu Saskiego

Fig.3. The disabled parking in the garage made during revitalization of the Saski Hotel

Zdolność adaptacyjna budynku (układu architektoniczno-konstrukcyjnego, ustroju nośnego, elementu konstrukcyjnego) jest to zespół cech i właściwości określających łatwość jego adaptacji do nowych warunków konstrukcyjnych (pracy w nowych układach konstrukcyjnych, implikujących nowe schematy statyczne, możliwości ich zmian, napraw, wymian, możliwości zmian obciążeń itp.) lub użytkowych [4]. Wartość zdolności adaptacyjnej może być określona po przeanalizowaniu wielu cech i właściwości, np.: materiałów - rodzajów, ich właściwości fizycznych, mechanicznych, wytrzymałościowych; technologii wykonania, współczesnej stosowalności, możliwości produkcji, właściwości geometrycznych, jakości, trwałości, łatwości wykonania przeróbek, napraw itp. Analizie zdolności adaptacyjnej powinien być poddany cały budynek, zwłaszcza jego ustrój konstrukcyjny (np. ustroje szkieletowe posiadają dużo większą zdolność adaptacyjną niż ustroje ścianowe) oraz wszystkie istotne elementy i układy konstrukcyjne: fundamenty, stropy, ściany, słupy, belki, konstrukcja dachu lub przekrycia.

Działania modernizacyjne i adaptacyjne zazwyczaj wymuszają ingerencję w układ architektoniczny i konstrukcyjny budynku. Mogą to być nowe otwory w przegrodach budowlanych - ścianach, stropach, bruzdy, wnęki, poszerzenia istniejących otworów, zmiana aranżacji pomieszczeń w postaci nowego układu ścianek działowych, mogącego powodować inne obciążenia na stropy, W skrajnym przypadku może być to nawet całkowita zmiana układu nośnego budynku (Rys.4). 


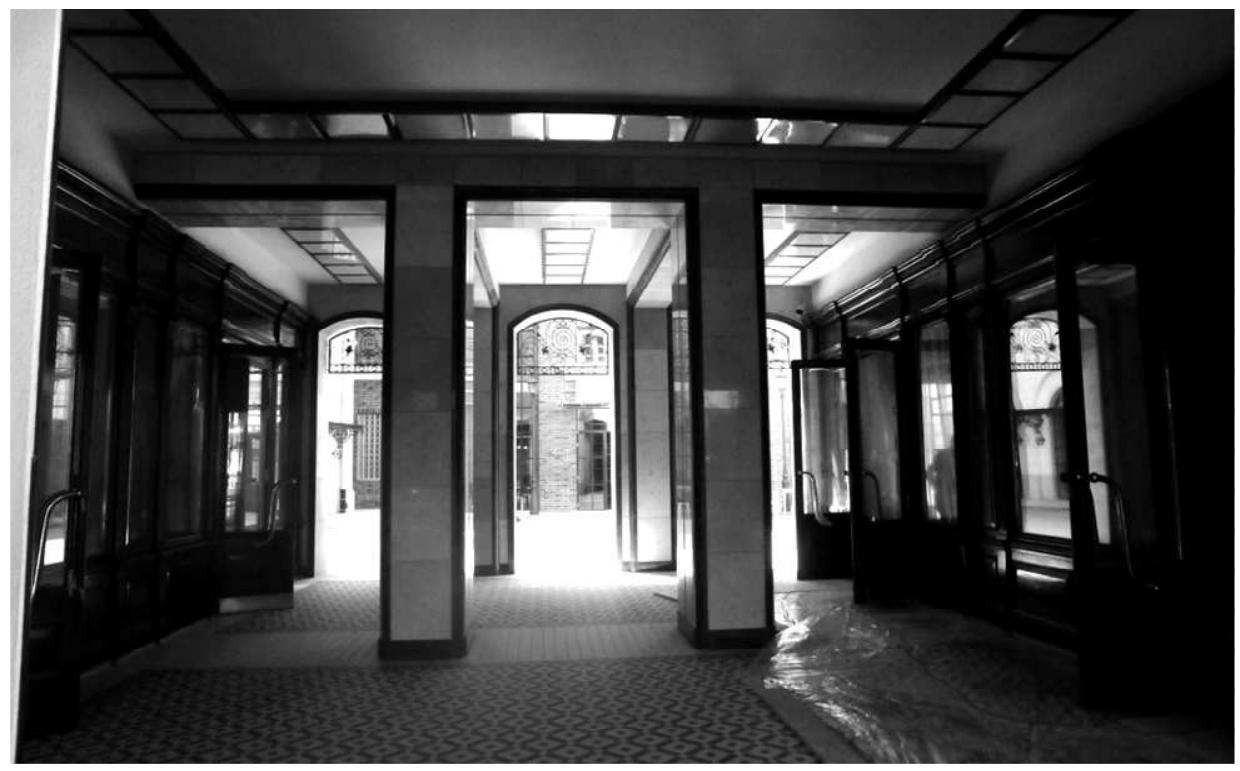

Rys.4. Zamieniony ustrój nośny ścianowy na ustrój szkieletowy (Hotel Saki w Warszawie)

Fig.4. Replacement of load bearing wall with frame structure (Saki Hotel in Warsaw)

Wszystkie działania inżynierskie $\mathrm{w}$ procesie rewitalizacji, dotyczące budynku (przede wszystkim jego konstrukcji), powinny być powiązane z właściwą diagnostyką stanu technicznego budynku zabytkowego, opartą na szczegółowych, rzetelnych badaniach. Powinny być one dokładnie zaplanowane i wykonane w sposób skoordynowany (uwzględniający istotną rolę konserwatora zabytków). Koordynacja powinna dotyczyć zarówno powiązań między ważnymi działaniami rehabilitacyjnymi, adaptacyjnymi, modernizacyjnymi, jak i pozostałymi działaniami rewitalizacyjnymi. Szczególne miejsce mają tutaj roboty konserwatorskie, dotyczące zarówno struktury budynku, jak również jego formy. Konserwacja sztuki w wypadku budynków zabytkowych jest konieczna w odniesieniu do zabytkowych detali i elementów architektonicznych, elewacji, ozdobnych wypraw i elementów wykończeniowych. Stwarza to na budowie sytuację, w której wiele ekip wykonawczych, reprezentujących różne branże, znajduje się jednocześnie w budynku i wykonuje swoje roboty. Niewłaściwa koordynacja tych prac może doprowadzić do sytuacji niebezpiecznych, w ostateczności nawet do katastrofy budowlanej. Schemat wzajemnych powiązań działań inżynierskich w procesie rewitalizacji budynku zabytkowego przedstawiony został na Rys. 5. 


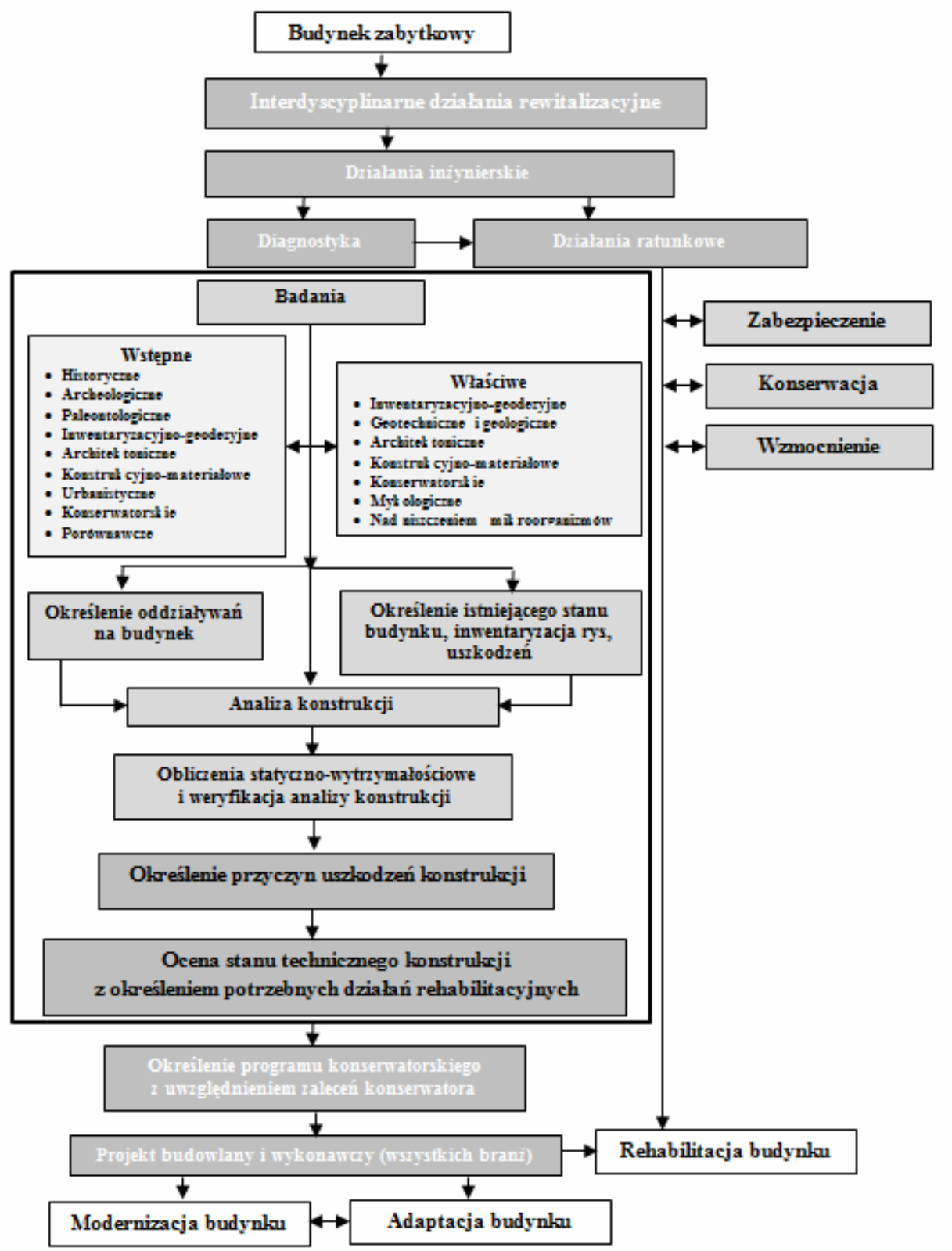

Rys.5. Schemat działań inżynierskich w procesie rewitalizacji budynku zabytkowego

Fig.5. The scheme of engineering activities in the historic building revitalization process 


\title{
4. Podsumowanie
}

W rewitalizacji obszarów kryzysowych szczególne miejsce ma rewitalizacja budynków zabytkowych. Wynika to z roli społecznej, edukacyjnej, historycznej zabytku, będącego częścią dziedzictwa kulturowego, o znaczeniu lokalnym, krajowym, regionalnym lub globalnym. Rewitalizacja zabytku może przyczynić się do rozwoju gospodarczego, zwłaszcza w zakresie turystyki, społecznego, edukacyjnego, pobudzenie przedsiębiorczości. Kluczowymi działaniami inżynierskimi w procesie rewitalizacji budynków zabytkowych jest rehabilitacja, modernizacja i adaptacja całego budynku i elementów go tworzących. Są to działania różniące się od siebie, uzupełniające się jednak i wynikające z siebie nawzajem. Mają one bardzo złożony charakter i powinny być odpowiednio zaplanowane i koordynowane $\mathrm{w}$ czasie realizacji. Powinny być realizowane zgodnie z programem konserwatorskim, uzgodnionym i zatwierdzonym przez konserwatora zabytków.

\section{Literatura}

[1] Rozporządzenie Ministra Kultury i Dziedzictwa Narodowego z dnia 27 lipca 2011 r. w sprawie prowadzenia prac konserwatorskich, prac restauratorskich, robót budowlanych, badań konserwatorskich, badań architektonicznych i innych działań przy zabytku wpisanym do rejestru zabytków oraz badań archeologicznych, Dz. U. 2011, nr 165.

[2] Rozporządzenie Ministra Infrastruktury z 12 kwietnia 2002r w sprawie warunków technicznych, jakim powinny odpowiadać budynki i ich usytuowanie. Dz. U. 2002r., Nr 75 z późniejszymi zmianami.

[3] Terlikowski W.: Rola badań w procesie rewitalizacji budynków zabytkowych, Miesięcznik „Materiały Budowlane” 8’2013 (nr 493), Warszawa 2013.

[4] Terlikowski W.: Zdolność rewitalizacyjna budynków użyteczności publicznej, Miesięcznik „Materiały Budowlane” 5’2013 (nr 490), Warszawa 2013.

[5] Ustawa z dnia 23 lipca 2003 r. o ochronie zabytków i opiece nad zabytkami, Dz.U. 2003, Nr 162, poz. 1568 z późniejszymi zmianami.

\section{THE REHABILITATION, MODERNIZATION AND ADAPTATION OF HISTORIC BUILDINGS IMPORTANCE IN THE REVITALIZATION PROCESS}

\author{
S u m m a r y \\ The aim of this article is to show the role of the rehabilitation, modernization and adapta- \\ tion, the main engineering activities, in the historic buildings revitalization process. Basing \\ on author's experience in the field of engineering and science, the analysis of this process \\ is made, including the problems, risks, and defining each activities. These activities are different \\ from each other, but complementary, and the resulting each other. They have very complex \\ nature and should be properly planned and coordinated during realization. They should be imple-
}


mented in accordance with the conservation program, which ought to be agreed and approved by the conservator. The historic building rehabilitation refers to the design, architectural form, including all details and architectural elements that give the aesthetic value of the monument, plant and equipment. The historic building modernization increases its use value, such as functional, aesthetic and comfort values. All rehabilitation, renovation and adaptive works, preceded by research and diagnostic should be carried out in a properly planned and coordinated manner including the important role of the conservator. Each historic building should be adapted to the modern utility requirements. Adaptive capacity of building, architecture and structural system, load bearing structure or structural element is a set of features and characteristics determining the possibility of adaptation to the new construction conditions (such as work in new structural systems, implying a new static schemes, the possibility of changes, repairs, replacements, the possibility of changes in loads etc.), or utility. The value of adaptive capacity can be determined by examining the many features and properties. The article presents a revitalization activities relation scheme.

Keywords: monuments conservation, adaptability, the sustainable development principles

Przestano do redakcji: 23.03.2015 r.

Przyjęto do druku: 22.06.2015 r.

DOI:10.7862/rb.2015.81 